\title{
Internal marketing and job satisfaction in hotels in Via Costeira, Natal, Brazil
}

\author{
Marketing interno e satisfação laboral em hotéis da Via Costeira, Natal, Brasil
}

\begin{abstract}
Carlos Peixeira Marques
CETRAD - The Centre for Transdisciplinary Development Studies, University of Trás-os-Montes and Alto Douro, Quinta de Prados, 5000-801 Vila Real, Portugal, cmarques@utad.pt
\end{abstract}

Carmem Teresa Leal

CETRAD - The Centre for Transdisciplinary Development Studies, University of Trás-os-Montes and Alto Douro, Quinta de Prados, 5000-801 Vila Real, Portugal, cleal@utad.pt

Carla Susana Marques

CETRAD - The Centre for Transdisciplinary Development Studies, University of Trás-os-Montes and Alto Douro, Quinta de Prados, 5000-801 Vila Real, Portugal, smarques@utad.pt

Breno Fernando Tinoco Cabral

Faculty of Economics, State University of Rio Grande do Norte, Avenida Ayrton Senna, 4241, Capim Macio, 59080100 - Natal, RN Brasil, brenotinoco@uern.br

\begin{abstract}
Organisations currently face multifaceted challenges, such as increasing productivity and coping with the pressure to manage human resources efficiently and effectively. This involves management practices focused on training and keeping the best employees. In this context, the present study sought to assess the impact of internal marketing practices in hotels of superior quality in a city in Brazil's Northeast Region on internal customers' commitment and satisfaction. Measures of internal market orientation, organisational commitment and job satisfaction were collected for a sample of 138 intermediate/lower managers from four hotels. The results from a structural equation model confirm the positive influence of internal marketing on organisational commitment and job satisfaction but fail to confirm the expected relationship between commitment and satisfaction.
\end{abstract}

Keywords: Internal marketing, organisational commitment, job satisfaction, hospitality.

\section{Resumo}

Atualmente as organizações enfrentam desafios multifacetados, como aumentar a produtividade e lidar com a pressão de gerir os recursos humanos de forma eficiente e eficaz, implicando práticas de gestão centradas na formação e retenção dos melhores colaboradores. Neste contexto, este artigo pretende avaliar o impacto de práticas de marketing interno no comprometimento e na satisfação dos trabalhadores de hotéis de qualidade superior numa cidade do Nordeste do Brasil. Foram recolhidas medidas da orientação para o marketing interno, comprometimento organizacional e satisfação laboral de 138 gestores operacionais e intermédios de quatro hotéis. Os resultados do modelo de equações estruturais confirmam o efeito positivo do marketing interno sobre o comprometimento e a satisfação, mas não confirmam a esperada relação entre comprometimento e satisfação.

Palavras-chave: Marketing interno, comprometimento organizacional, satisfação laboral, hotelaria.

\section{Introduction}

Currently, tourism is extremely important in the growth and development of a variety of regions. According to the World Tourism Organisation (UNWTO, 2015), tourism has developed into a major promoter of economic recovery, creating jobs and opportunities in many parts of the world. According to the cited source, tourism has continually expanded and diversified over the last six decades, becoming one of the largest and fastest growing economic sectors worldwide.

Carvalho and Sarkar (2014) characterise the hospitality sector as highly heterogeneous, given that a region can have both luxury hotels with golf courses and small family-managed restaurants or guest houses. The hospitality industry is especially concerned about providing the best level of service, as excellent service meets the needs of the 'new', more informed and demanding guests of today. Therefore, hotels constantly need to adapt their management practices. This adaptation can involve management guiding employees in their use of new paths and tools (Pechlaner, Kozak \& Volgger, 2014). Pereira-Moliner, Claver-Cortés, Molina-Azorín and José Tarí (2012) argue that management practices related to leadership, motivation of human resources and guidance of stakeholders can lead to better performance, resulting in high quality services and customers' deep satisfaction with tourism experiences.

The present study, thus, sought to develop a structural model for the hospitality industry and evaluate the basis of employee satisfaction, focusing, in particular, on the importance of internal marketing within these firms. In this context, this research applies a measure of internal marketing orientation that was previously validated with a sample of hotel employees. This approach was used to evaluate the impact of internal marketing practices on top quality hotels in a city in northeastern Brazil, in terms of the commitment and satisfaction levels of internal customers. 


\section{Literature review}

\subsection{Internal marketing}

The concept of internal marketing was introduced by Berry, Hensel and Burke, 1976. Later on, Berry (1981, p. 34) defined it as 'viewing employees as internal customers, viewing jobs as internal products, and then endeavouring to offer internal products that satisfy the needs and wants of these internal customers while addressing the objectives of the organization'. According to Lings and Greenley (2010), internal marketing implies a perspective centred around human resources management, based on the conceptualisation of individuals' work as the main component of firms' final products. For the cited authors, investment in internal marketing practices has a positive influence on the behaviour of staff, particularly with regard to their market orientation. Lings and Greenley (2010) add that both dimensions of marketing (i.e. internal and external) must therefore be balanced, without subordinating the needs and expectations of employees at the expense of the wishes of managers or shareholders. Hee Yoon, Beatty and Suh (2001) present similar conclusions, pointing out that, in the service sector, some internal marketing practices can positively and directly affect employees' behaviours and satisfaction levels, which then influence customer perceptions of quality of service.

Seen from another angle, a changed perspective on the relationship between employees and their organisations (TagEldeen \& El-Said, 2011) suggests that employees can participate in decision making and enhance management's knowledge of their companies' current state of affairs, motivating staff to work more actively towards their companies' goals. This approach also makes the importance of internal marketing more obvious, primarily in the formation of more committed and motivated employees who can provide quality services and thus establish competitive advantages in the service sector. With regard to front office staff, this relevance is even more apparent, as these employees are critical success factors for companies since staff are responsible for how customers evaluate services and employees contribute to clients' satisfaction and retention (Lovelock \& Wirtz, 2004; Wu, Tsai \& Zhou, 2011).

\subsection{Organisational commitment}

Organisational commitment is commonly defined as a psychological link between employees and their organisation, which can reduce the likelihood of employees voluntarily leaving the organisation (Meyer \& Allen, 1991). In Mukerjee's (2014) opinion, organisational commitment should be a key concern for managers because of its close relationship with outcomes such as attitude and job satisfaction, which are associated with performance and quality of work (Hackett, Bycio \& Hausdorf, 1991). Mowday, Steers and Porter (1979) report that definitions of organisational commitment can vary considerably, including relationship bonds or behaviours that exceed formal expectations or regulations. A clear conceptualisation must separate what is a staff function and what goes beyond that function. Allen and Meyer (1996) define organisational commitment as a key factor in motivation, retention and of employees' satisfaction, resulting in a quite complex, multidimensional concept. It can also be explained as employee identification with the relevant organisation (Mathieu \& Zajac, 1990), in the sense that staff believe in their company's values, goals and mission (Lee, Park \& Yoo, 1999).

\subsection{Relationship between internal marketing and organisational commitment}

Lings and Greenley (2010) observe that the establishment of internal marketing practices involves generating and disseminating information that meets the needs of employees, in addition to reflecting a strategic orientation of companies that includes caring about employee well-being. By using internal communication channels to disseminate their vision and goals, organisations define what they expect from their employees. This kind of collaborative management involves all employees in the process of identifying and defining company goals and values through internal communication channels, which can be understood as a way of stimulating organisational commitment (Locke \& Latham, 2002; Mowday et al., 1979; Sahai \& Srivastava, 2012). In line with these findings, Wu et al. (2011) and Kim, Leong and Lee's (2005) research highlights that the greater the investment in internal marketing practices, the stronger employees' organisational commitment will be. However, some authors, such as Cascio, Mariadoss and Mouri (2010) and Clark, Hartline and Jones (2008), found an indirect relationship between internal marketing and organisational commitment, which was mediated by job satisfaction. Taking into account the literature review conducted, we chose to test the following research hypothesis:

H1: Internal marketing has a positive influence on organisational commitment.

\subsection{Job satisfaction}

In general, job satisfaction is defined as a set of affective reactions or attitudinal evaluations of a job or specific aspects of a job (Spector, 1985). According to the cited author, besides an overall feeling of satisfaction, there is also a perceptualcognitive disconfirmation of certain job features, compared to worker expectations. In the service sector, these perceptions are particularly relevant due to their empirically confirmed connection to organisational results (e.g. employee turnover rate). Job satisfaction thus affects how individuals perceive various aspects directly or indirectly related to their work, resulting in 'potential effects' on organisational and professional performance, individual behaviour and workers' physical and psychological well-being. Satisfaction influences behaviours such as turnover and absenteeism and several work-related attitudes that, in turn, influence the productivity and competitiveness of hotels (Davy, Kinicki \& Scheck, 1991; Susskind, Borchgrevink, Michele Kacmar \& Brymer, 2000). 


\subsection{Relationship between internal marketing and job} satisfaction

For authors such as Huang and Rundle-Thiele (2014), internal marketing practices have a strong positive influence on job satisfaction, particularly in the hospitality industry (Yang, 2010). Lee and Way's (2010) study, which was conducted in about 400 hotel units, revealed that hotel employees are more sensitive to communication and trust within their work team and in relationships with their leaders, than to financial compensation. Based on these findings, we defined the second hypothesis to be tested as:

H2: Internal marketing has a positive influence on job satisfaction.

\subsection{Relationship between commitment and job satisfaction}

A positive impact on job satisfaction is an intrinsic characteristic of the original conceptual definition of organisational commitment (Mowday et al., 1979). Along these lines, numerous academic studies have shown satisfaction to be a result of commitment. Even though the inverse relationship is also common in the literature (Eslami \& Gharakhani, 2012; Peters, Lau \& Ng, 2014; Yang, 2010), we chose to test the following hypothesis:

H3: Commitment has a positive influence on job satisfaction.

\section{Methodology}

This study sought to develop a structural model to evaluate the importance of internal marketing on employee satisfaction within the hospitality industry. The model used (see Figure 1) involves the constructs of internal marketing, organisational commitment and job satisfaction and displays their relationships as defined by the hypotheses set out in the previous section.

\section{Figure 1 - Conceptual model}

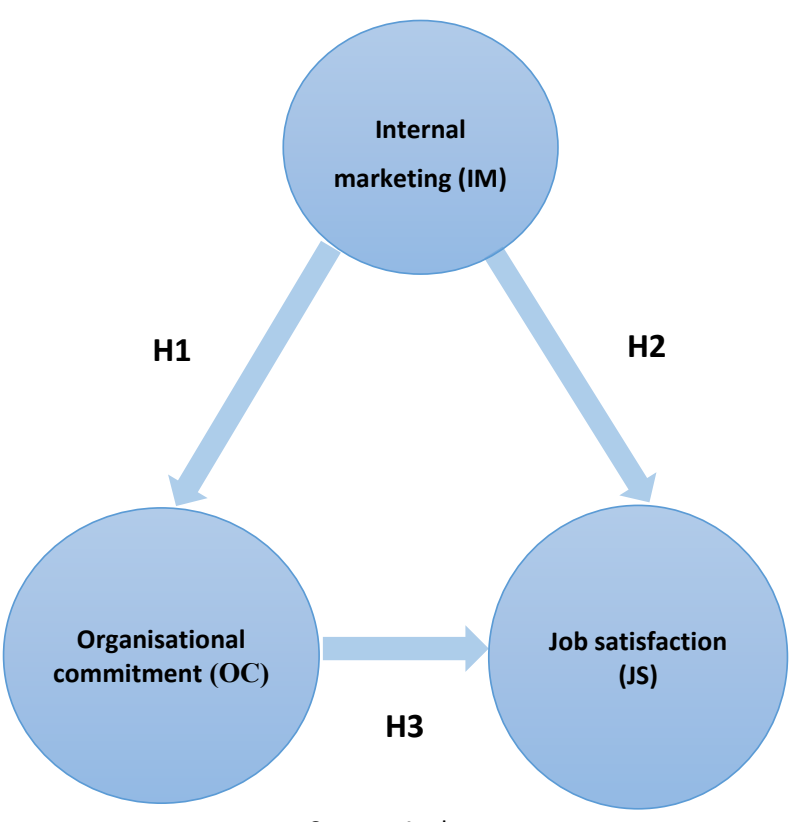

Source: Authors.
The data collection instrument was a questionnaire distributed to intermediate/lower managers of four five-star hotels in Via Costeira, in the city of Natal, Rio Grande do Norte, Brazil. The first section included background variables in order to profile the employees (i.e. job tenure and function, sex, age, education and income), while the second section consisted of items that measure employees' commitment and satisfaction, as well as their beliefs about their hotel's internal marketing orientation. In addition, the survey included questions about the perceived quality of service, a variable that is not directly discussed in this paper.

To measure internal marketing, a traditional model of three dimensions was adopted: information generation, dissemination of internal information and management responses to internal marketing information. Items were taken from a scale validated by García Rodríguez, Álvarez and Vijande (2011) with a sample of hotel managers. Organisational commitment was measured with nine questions validated in Portugal by Gomes (2006), based on the scale developed by Mowday et al. (1979). The satisfaction items were adapted to a work context (i.e. by considering the job/work, instead of services, as the object of satisfaction) from the Portuguese version of the European Customer Satisfaction Index (Fornell, Johnson, Anderson, Cha, \& Bryant, 1996). All items were evaluated on a seven-point Likert scale. Internal marketing and commitment were measured on an agreement scale ( $1=$ 'strongly disagree', 7 = 'strongly agree'). Job satisfaction used a dis/satisfaction scale $(1=$ 'completely dissatisfied', $7=$ 'completely satisfied').

The target population of this study consisted of 245 employees from the selected hotels - SERHS, Pestana, Ocean Palace and Pyramid. The sample was obtained by applying a nonprobability method, resulting in a total of 138 participants. The sample profile is gender balanced, with $51 \%$ males, but it is mostly composed by young ( $62 \%$ between 20 and 40 years old) well educated (69\% with tertiary education) professionals, working at supervision (47\%) or co-ordination (44\%) positions. The survey was conducted between 21 January and 7 April, 2013.

To evaluate the proposed model, the measurements were first validated through confirmatory factor analysis. According to Hair, Black, Babin and Anderson's (2010) guidelines for how to apply Fornell and Larcker's (1981) propositions, measures of latent variables can be accepted if the composite reliability (CR) is greater than 0.7 , the average variance extracted (AVE) is greater than $50 \%$ and the average of items' factor loadings is higher than any correlation between this variable and every other latent variable. Since it was necessary to assess whether organisational commitment mediates the relationship between internal marketing and job satisfaction, the present study's structural analysis followed the procedures proposed by Shrout and Bolger (2002) for mediation analysis. 


\section{Results}

Internal marketing involves the generation and dissemination of information and the design and implementation of management's appropriate responses to employees' needs and wants. Table 1 shows that, among the three dimensions of internal marketing, dissemination of information has the lowest rating from the participating employees. These results indicate that the hotels selected are failing to disseminate information concerning problems and difficulties faced by employees when performing their duties. Nevertheless, staff do believe that the administration is effectively managing their responses to the information, offering appropriate training and keeping the best human resources.

Table 1 - Measurement model

\begin{tabular}{|c|c|c|c|c|c|c|}
\hline Dimension/Item & Mean & Median & $\begin{array}{l}\text { Std. } \\
\text { Dev. }\end{array}$ & Loading & Sig. & $\begin{array}{l}\text { Variance } \\
\text { Extracted }\end{array}$ \\
\hline \multicolumn{7}{|c|}{ Internal Marketing - Generation of Information } \\
\hline $\begin{array}{l}\text { The hotel management knows the work-related needs and } \\
\text { expectations of its employees. }\end{array}$ & 5.1 & 5.0 & 1.4 & 0.778 & 0.002 & 0.605 \\
\hline $\begin{array}{l}\text { The administration knows the work-related needs of each category } \\
\text { of hotel employee. }\end{array}$ & 3.6 & 3.0 & 1.5 & 0.706 & 0.001 & 0.498 \\
\hline $\begin{array}{l}\text { Human resource policies take into account the characteristics of } \\
\text { each category of hotel employee. }\end{array}$ & 5.6 & 6.0 & 1.0 & 0.646 & 0.001 & 0.417 \\
\hline \multicolumn{7}{|c|}{ Internal Marketing - Dissemination of Information } \\
\hline $\begin{array}{l}\text { Leaders are willing to listen to employees discuss problems they } \\
\text { face. }\end{array}$ & 3.8 & 4.0 & 1.3 & 0.803 & 0.001 & 0.645 \\
\hline $\begin{array}{l}\text { Information about the problems of employees is shared among } \\
\text { leaders. }\end{array}$ & 3.6 & 3.0 & 1.5 & 0.651 & 0.001 & 0.424 \\
\hline $\begin{array}{l}\text { The administration is informed about the problems and difficulties } \\
\text { that employees have when performing their duties. }\end{array}$ & 3.8 & 4.0 & 1.3 & 0.760 & 0.001 & 0.578 \\
\hline \multicolumn{7}{|c|}{ Internal Marketing - Response to Information } \\
\hline $\begin{array}{l}\text { The hotel acts based on the understanding that employees are its } \\
\text { main resource. }\end{array}$ & 6.1 & 7.0 & 1.1 & 0.744 & 0.001 & 0.554 \\
\hline $\begin{array}{l}\text { The human resource policies seek actively to improve employees' } \\
\text { job conditions and satisfaction. }\end{array}$ & 5.8 & 7.0 & 1.6 & 0.680 & 0.002 & 0.462 \\
\hline Employees receive training according to their needs. & 6.2 & 7.0 & 1.1 & 0.763 & 0.001 & 0.582 \\
\hline \multicolumn{7}{|c|}{ Organisational Commitment } \\
\hline $\begin{array}{l}\text { I am willing to put in a great deal of effort beyond that normally } \\
\text { expected, to help this hotel be successful. }\end{array}$ & 3.1 & 3.0 & 1.1 & 0.479 & 0.001 & 0.229 \\
\hline I talk up this hotel to my friends as a great hotel to work for. & 3.0 & 3.0 & 1.1 & 0.566 & 0.001 & 0.320 \\
\hline $\begin{array}{l}\text { I would accept almost any type of job assignment in order to keep } \\
\text { working in this hotel. }\end{array}$ & 3.1 & 3.0 & 1.1 & 0.557 & 0.001 & 0.310 \\
\hline I think my personal values and the values of this hotel are similar. & 5.5 & 6.0 & 1.3 & 0.668 & 0.001 & 0.446 \\
\hline I am proud to tell others that I am part of this hotel. & 5.2 & 5.0 & 1.6 & 0.788 & 0.001 & 0.621 \\
\hline This hotel inspires me in the way of job performance. & 5.3 & 5.0 & 1.6 & 0.677 & 0.001 & 0.458 \\
\hline I am extremely glad that I chose this hotel to work for. & 6.0 & 6.0 & 1.0 & 0.836 & 0.002 & 0.699 \\
\hline I really care about the fate of this hotel. & 6.1 & 6.0 & 1.0 & 0.670 & 0.002 & 0.449 \\
\hline For me, this is the best hotel to work for. & 6.2 & 7.0 & 1.1 & 0.775 & 0.001 & 0.601 \\
\hline \multicolumn{7}{|c|}{ Job Satisfaction } \\
\hline What is your level of satisfaction with your work here? & 6.1 & 7.0 & 1.2 & 0.879 & 0.001 & 0.773 \\
\hline $\begin{array}{l}\text { What is your level of job satisfaction compared to your } \\
\text { expectations? }\end{array}$ & 6.1 & 7.0 & 1.2 & 0.779 & 0.001 & 0.607 \\
\hline $\begin{array}{l}\text { What is your level of satisfaction with this job compared to what it } \\
\text { would be in the ideal hotel to work for? }\end{array}$ & 6.0 & 6.5 & 1.2 & 0.850 & 0.002 & 0.723 \\
\hline
\end{tabular}

Note: Items in italics were removed from the final measurement model.

Source: Authors.

The construct of satisfaction has the best rating of all the factors that make up the proposed theoretical model, obtaining an average of 6.1 out of seven points possible. This assessment may indicate that, in general, employees believe an appropriate relationship exists between what they expect of their work and what they perceive they have experienced.

Regarding organisational commitment, the ratings suggest that employees are affectively attached to their hotel and satisfied with the decision to work there, but they do not want to keep their job at any price, that is, they are not willing to exert much more effort than they do now to guarantee their hotel's success and, ultimately, their best job performance. The items with the smallest scores (i.e. in italics) have smaller correlations than the rest of the scale, resulting in poor factor loadings and high measurement error. These items, thus, were excluded from further analyses. 
After withdrawing these three items, the latent variable of organisational commitment now presents convergent validity (AVE $=0.548)$, while maintaining a high CR value (0.878) (see Table 2). Items of all other latent variables have satisfactory values of variance extracted, thus providing an AVE greater than 0.5 for all variables, which attests to the model's convergent validity. The CR also is higher than 0.7 in all cases. As can be seen in Table 2, the averages of factor loadings are higher than the correlation coefficients, which is why, although related, all these latent variables represent discriminated concepts or dimensions. Measures of goodness of fit reinforce the confidence on the measurements' validity: $\chi^{2} /$ d.f. $=1.438 ; C F I=$ $0.95 ;$ RMSEA $=0.057 ;$ p $($ RMSEA $) \leq 0.05=0.271$.

Table 2 - Measures of validity and reliability

\begin{tabular}{|c|c|c|c|c|c|c|c|}
\hline & CR & AVE & OC & GER & DIS & RES & ST \\
\hline OC & 0.878 & 0.548 & $\mathbf{0 . 7 4 0}$ & & & & \\
\hline GER & 0.754 & 0.507 & 0.522 & $\mathbf{0 . 7 1 2}$ & & & \\
\hline DIS & 0.784 & 0.549 & 0.405 & 0.642 & $\mathbf{0 . 7 4 1}$ & & \\
\hline RES & 0.773 & 0.532 & 0.577 & 0.392 & 0.518 & $\mathbf{0 . 7 3 0}$ & \\
\hline ST & 0.875 & 0.701 & 0.545 & 0.373 & 0.363 & 0.519 & $\mathbf{0 . 8 3 7}$ \\
\hline
\end{tabular}

Note: The figures in bold on the diagonal represent the square root of AVE (or the average of the factor loadings of the respective items). Values in italics are the correlation coefficients between the latent variables.

\section{Source: Authors.}

After the measurement model was validated by confirming that its constructs are reliable and valid, the structural model was evaluated by analysing the structural relationships between the latent variables presented in the aforementioned hypotheses (see Figure 1 above). Since internal marketing is conceptualised as a second-order variable, the direct effects of the three proposed relationships, estimated using bootstrapping, are presented in Table 3 below. Given that the relationship between commitment and satisfaction is shown to be statistically non-significant, the indirect effect of internal marketing on satisfaction also is non-significant. The model has an acceptable goodness of fit, as indicated by the statistics: $\chi^{2} /$ d.f. $=1.504 ; \mathrm{CFI}=0.941 ; \mathrm{RMSEA}=0.061 ; \mathrm{p}(\mathrm{RMSEA}) \leq 0.05=$ 0.158

Table 3 - Estimates of direct effects

\begin{tabular}{|l|c|c|}
\hline \multicolumn{1}{|c|}{ Direct Effect } & Effect & Sig. \\
\hline Internal Marketing $\rightarrow$ Commitment & 0.698 & 0.001 \\
\hline Internal Marketing $\rightarrow$ Satisfaction & 0.401 & 0.002 \\
\hline Commitment $\rightarrow$ Satisfaction & 0.266 & 0.181 \\
\hline \multicolumn{2}{|c|}{ Source: Authors. } & \\
\hline
\end{tabular}

Based on Table 3 and an analysis of the significance levels, hypotheses $\mathrm{H} 1$ (i.e. internal marketing has a positive influence on organisational commitment) and $\mathrm{H} 2$ (i.e. internal marketing has a positive influence on job satisfaction) can be considered verified. However, the third hypothesis (i.e. H3: organisational commitment has a positive influence on job satisfaction) could not be confirmed (Sig. $=0.181$ ).

\section{Conclusions}

Organisations currently face multi-faceted challenges in how not only to increase productivity but also to deal with the pressure to manage their human resources efficiently and effectively, including training and keeping their best employees. Management practices and policies, therefore, must seek to overcome these challenges. In this context, the present study sought to analyse the contribution of internal marketing to workers' satisfaction levels in top category hotels.

To this end, a conceptual model was validated using structural equation modelling to analyse the role of internal marketing and organisational commitment in workers' job satisfaction for hotels in Via Costeira, in the city of Natal, Rio Grande do Norte, Brazil. The results show a positive and statistically significant relationship between organisational commitment and the latent variable of internal marketing orientation. This means that, when a system of internal marketing is correctly implemented, this has a positive influence on organisational commitment. The results also confirm that a positive and statistically significant relationship exists between internal marketing and workers' satisfaction. These findings highlight the importance of internal marketing when management seeks to create a positive image of the workplace in employees' minds.

However, the results do not confirm a statistically significant relationship between organisational commitment and job satisfaction, a finding that is in agreement with some studies that found an ambiguous and inconsistent relationship between these dimensions (Moynihan, Boswell \& Boudreau, 2000). Nonetheless, the use of a measure of satisfaction adapted for consumer surveys, instead of a measure specifically focused on job satisfaction, may help to explain the present results.

The current study provides evidence of internal marketing's crucial importance in hotel management, since this practice affects workers' job satisfaction and commitment to their hotel. In this way, management must acknowledge that employees are internal clients of their hotel firms, which then allows managers to apply marketing tools and techniques in this context. It also unveils the need to further explore why respondents consider that the organization is responsive to employees' needs, despite the ineffective flow of information regarding the same employees. 
Some methodological limitations need to be considered when interpreting the above results. Although the sample collected was adequate for the purposes of this study, the sample cannot be considered representative of the general population. Sampling was limited to one single Brazilian city and extracted only from top-quality large hotels, which partially limits the generalisability of the results. Furthermore, this study did not test for the existence of a relationship between workers' satisfaction and performance levels, as suggested in the literature (Ahearne, Jelinek \& Rapp, 2005; Williams \& Anderson, 1991).

These limitations suggest several future avenues of research. First, new studies can expand this research geographically. Second, the model's applicability can be tested for other patterns and segments of the hospitality industry. In future research, the results also can be divided by categories of employees and hotels. Third, researchers can study the direct relationships between dependent variables and the three dimensions of internal marketing (i.e. information generation, internal dissemination of information and management responses). And last, employees' turnover intentions and perceptions of service delivery may be considered as dependent variables.

In conclusion, the above findings indicate that hotel managers need to focus more directly on developing their employees' competencies in order to improve quality of service, job satisfaction, best employee retention and worker performance, as well as reducing turnover. In this way, hotels can achieve high standards of quality and develop distinctive services that can satisfy the needs of a patronage that is increasingly well informed and demanding, thus allowing hotels to reach a strategic level of differentiation in the market.

\section{Acknowledgments}

This work is partially supported by the European Structural and Investment Funds' FEDER component, through the Operational Competitiveness and Internationalization Program (COMPETE 2020) (Project No. 006971 [UID/SOC/04011]), and national funds, through the FCT-Portuguese Foundation for Science and Technology through the UID/SOC/04011/2013 project.

\section{References}

Ahearne, M., Jelinek, R., \& Rapp, A. (2005). Moving beyond the direct effect of SFA adoption on salesperson performance: Training and support as key moderating factors. Industrial Marketing Management, 34(4 SPEC ISS.), 379-388. Doi: 10.1016/j.indmarman.2004.09.020

Allen, N. J., \& Meyer, J. P. (1996). Affective, Continuance, and Normative Commitment to the Organization: An Examination of Construct Validity. Journal of Vocational Behavior, 49(3), 252-276. Doi: 10.1006/jvbe.1996.0043

Berry, L. L. (1981). The Employee as Customer. Journal of Retail Banking, III(1), 33-40.

Berry, L. L., Hensel, J. S., \& Burke, M. C. (1976). Improving retailer capability for effective consumerism response. Journal of Retailing, 52(3).

Carvalho, L. M. C., \& Sarkar, S. (2014). Market structures, strategy and innovation in tourism sector. International Journal of Culture, Tourism and Hospitality Research, 8(2), 153-172. Doi: 10.1108/IJCTHR-05-2013-0031

Cascio, R., Mariadoss, B. J., \& Mouri, N. (2010). The impact of management commitment alignment on salespersons' adoption of sales force automation technologies: An empirical investigation. Industrial Marketing Management, 39(7), 1088-1096. Doi: 10.1016/j.indmarman.2009.12.010
Clark, R. A., Hartline, M. D., \& Jones, K. C. (2008). The Effects of Leadership Style on Hotel Employees' Commitment to Service Quality. Cornell Hospitality Quarterly, 50(2), 209-231. Doi: 10.1177/1938965508315371

Davy, J. A., Kinicki, A. J., \& Scheck, C. L. (1991). Developing and testing a model of survivor responses to layoffs. Journal of Vocational Behavior, 38(3), 302-317. Doi: 10.1016/0001-8791(91)90032-H

Eslami, J., \& Gharakhani, D. (2012). Organizational Commitment and Job Satisfaction. Journal of Science and Technology, 2(2), 85-91.

Fornell, C., Johnson, M. D., Anderson, E. W., Cha, J., \& Bryant, B. E. (1996). The American Customer Satisfaction Index: Nature, Purpose, and Findings. Journal of Marketing, 60(4), 7. Doi: 10.2307/1251898

Fornell, C., \& Larcker, D. (1981). Evaluating structural equation models with unobservable variables and measurement error. Journal of Marketing Research, 18(3), 39-50. Doi: 10.2307/3151312

García Rodríguez, N., Álvarez, B., \& Vijande, M. . L. S. (2011). Aplicación de la Lógica Dominante del servicio (LDS) en el sector turístico: el marketing interno como antecedente de la cultura de co-creación de innovaciones con clientes y empleados. Cuadernos de Gestión, 11(2), 53-75. Retrieved from http://www.redalyc.org/articulo.oa?id=274320119003

Gomes. (2006). Escala de comprometimento organizacional (ECO) - Versão para investigação. Universidade do Minho.

Hackett, Rick D.; Bycio, Peter; Hausdorf, P. A. (1991). Further assessments of Meyer and Allen's (1991) three-component model of organizational commitment. Human Resource Management Review, 1(1), 61-89.

Hair, J. F., Black, W. C., Babin, B. J., \& Anderson, R. E. (2010). Multivariate Data Analysis. Vectors. Doi: 10.1016/j.ijpharm.2011.02.019

Huang, Y.-T., \& Rundle-Thiele, S. (2014). The moderating effect of cultural congruence on the internal marketing practice and employee satisfaction relationship: An empirical examination of Australian and Taiwanese born tourism employees. Tourism Management, 42, 196-206. Doi: 10.1016/j.tourman.2013.12.005

Kim, W. G., Leong, J. K., \& Lee, Y. K. (2005). Effect of service orientation on job satisfaction, organizational commitment, and intention of leaving in a casual dining chain restaurant. International Journal of Hospitality Management, 24(2), 171-193. Doi: 10.1016/j.ijhm.2004.05.004

Lee, C., \& Way, K. (2010). Individual employment characteristics of hotel employees that play a role in employee satisfaction and work retention. International Journal of Hospitality Management, 29(3), 344-353. Doi: 10.1016/j.ijhm.2009.08.008

Lee, Y. K., Park, D. H., \& Yoo, D. K. (1999). The structural relationships between service orientation, mediators, and business performance in Korean hotel firms. Asia Pacific Journal of Tourism Research, 4(1), 59-70. Doi: 10.1080/10941669908722031

Lings, I. N., \& Greenley, G. E. (2010). Internal market orientation and marketoriented behaviours. Journal of Service Management, 21(3), 321-343. Doi: 10.1108/09564231011050788

Locke, E., \& Latham, G. (2002). Building a practically useful theory of goal setting and task motivation. A 35-year odyssey. The American Psychologist, 57(9), 705717. Doi: 10.1037/0003-066X.57.9.705

Lovelock, C., \& Wirtz, J. (2004). Services Marketing: People, Technology, Strategy, (January 2011).

Mathieu, J. E., \& Zajac, D. M. (1990). A review and meta-analysis of the antecedents, correlates, and consequences of organizational commitment. Psychological Bulletin, 108(2), 171-194.

Meyer, J. P., \& Allen, N. J. (1991). A three-component conceptualization of organizational commitment. Human Resource Management Review, 1(1), 61-89. Doi: 10.1016/1053-4822(91)90011-Z

Mowday, R. T., Steers, R. M., \& Porter, L. W. (1979). The measurement of organizational commitment. Journal of Vocational Behavior, 14(2), 224-247. Doi: 10.1016/0001-8791(79)90072-1

Moynihan, L.M., Boswell, W.R., \& Boudreau, J. W. (2000). The influence of job satisfaction and organizational commitment on executive withdrawal and performance. (CAHRS Working Paper 00-16). Ithaca, NY: Cornell University.

Mukerjee, K. (2014). Fostering employee engagement in organisations: a conceptual framework. International Journal of Management Practice, 7(2), 160176. Doi: 10.1504/IJMP.2014.061476

Pechlaner, H., Kozak, M., \& Volgger, M. (2014). Destination leadership: a new paradigm for tourist destinations? Tourism Review, 69(1), 1-9. Doi: 10.1108/TR09-2013-0053

Pereira-Moliner, J., Claver-Cortés, E., Molina-Azorín, J. F., \& José Tarí, J. (2012). Quality management, environmental management and firm performance: direct and mediating effects in the hotel industry. Journal of Cleaner Production, 37, 8292. Doi: $10.1016 /$ j.jclepro.2012.06.010 
Peters, S., Lau, T.-C., \& Ng, C.-Y. (2014). Determinants of job satisfaction and ethical behaviour towards organisational commitment-a review. ... Journal of Academic Research in Business ..., 4(7), 573-592. Doi: 10.6007/JARBSS/v4$\mathrm{i} 7 / 1052$

Sahai, S., \& Srivastava, A. K. (2012). Goal / target Setting and Performance Assessment as Tool for Talent Management. Procedia - Social and Behavioral Sciences, 37, 241-246. Doi: 10.1016/j.sbspro.2012.03.290

Shrout, P. E., \& Bolger, N. (2002). Mediation in experimental and nonexperimental studies: new procedures and recommendations. Psychological Methods, 7(4), 422. Doi: $10.1037 / / 1082-989 x .7 .4 .422$

Spector, P. E. (1985). Measurement of Human Service Staff Satisfaction: Development of the Job Satisfaction Survey. American Journal of Community Psychology, 13(6), 693.

Susskind, A. M., Borchgrevink, C. P., Michele Kacmar, K., \& Brymer, R. A. (2000). Customer service employees' behavioral intentions and attitudes: an examination of construct validity and a path model. International Journal of Hospitality Management, 19(1), 53-77. Doi: 10.1016/S0278-4319(99)00030-4

Tag-Eldeen, A., \& El-Said, O. A. (2011). Implementation of internal marketing on a sample of Egyptian five-star hotels. Anatolia, 22(2), 153-167. Doi: 10.1080/13032917.2011.597931

UNWTO. (2015). 21 million more international tourists in the first half of 2015 | World Tourism Organization UNWTO. Retrieved May 26, 2016, from http://media.unwto.org

Williams, L. J., \& Anderson, S. E. (1991). Job satisfaction and organizational commitment as predictors of organizational citizenship and in-role behaviors. Journal of Management. Doi: 10.1177/014920639101700305

Wu, J., Tsai, H., \& Zhou, Z. (2011). Improving efficiency in international tourist hotels in Taipei using a non-radial DEA model. International Journal of Contemporary Hospitality Management, 23(1), 66-83. Doi: 10.1108/09596111111101670

Yang, J. Te. (2010). Antecedents and consequences of job satisfaction in the hotel industry. International Journal of Hospitality Management, 29(4), 609-619. Doi: 10.1016/j.jjhm.2009.11.002

Received: 15 February 2017

Revisions required: 14 May 2017

Accepted: 18 July 2017 